Proceedings

\title{
Evaluation of Seeds Moringa oleifera Lam. Present in Urban Forests as a Coagulant-Flocculant for Water Treatment ${ }^{\dagger}$
}

\author{
Simón Urrea-Florián ${ }^{1}$ and Alfredo Torres-Benítez ${ }^{2, *}$ \\ 1 Servicio Nacional de Aprendizaje-SENA, Ibagué, Colombia; simon45urrea@gmail.com \\ 2 Instituto de Farmacia, Facultad de Ciencias, Universidad Austral de Chile, Valdivia 509000, Chile \\ * Correspondence: aljotobe19@hotmail.com; Tel.: +57-9-90549002 \\ + Presented at the 1st International Electronic Conference on Plant Science, 1-15 December 2020; Available \\ online: https://iecps2020.sciforum.net/.
}

Published: 30 November 2020

\begin{abstract}
The objective of the work was to evaluate the efficiency of Moringa oleifera seeds as a natural coagulant-flocculant in the treatment of water for human consumption. Seeds were collected from trees present in forest remnants of the city of Ibagué (Colombia), dried, pulverized and subjected to the process of extraction of the active agents from organic solvents; samples were taken from river surface waters and with a latin square design (DCL) that grouped two factors (water $\mathrm{pH}$ and extract dosage), the coagulant action was evaluated in the tests carried out with jar tests. According to the ranges of $\mathrm{pH}(4,5,6$ and 7$)$ and dosages (5, 10,15 and $20 \mathrm{~mL}$ ) used, a greater reduction of the turbidity values was obtained in the conditions of $\mathrm{pH} 6$ with a dosage of $10 \mathrm{~mL}$ of coagulant solution, and $\mathrm{pH} 7$ with a dosage of $10 \mathrm{~mL}$ of coagulant solution. The tests carried out showed that the coagulation-flocculation levels of moringa seeds do not vary significantly concerning the reports in the literature for Colombia, their performance is associated with the factors established in the experimental design and maintains experimental efficiency against coagulants conventionals used for the purification of water.
\end{abstract}

Keywords: Moringa oleifera; seeds; coagulant-flocculant; treatment; water

\section{Introduction}

Water treatment is a process in which it seeks to remove or eliminate organic matter, silt, sand, and analyze the physicochemical and microbiological characteristics through regulations, to make it optimal for human consumption. Natural organic polymers have been used for over 4000 years in India, Africa, and China as efficient coagulants and as coagulation aids for high turbidity waters for domestic use in rural areas [1]. Starting in the 19th century, chemical coagulants such as ferric chloride $\left(\mathrm{FeCl}_{3}\right)$ and Aluminum sulfate $\mathrm{Al}\left(\mathrm{SO}_{4}\right)_{3}$ began to be used around the world in the treatment of water for human consumption, which left the use of coagulants in the background, except in rural and developing countries that still use them [2]. However, chemical coagulants have impacted the environment and human health [3] due to its composition and higher cost. For this reason, the present investigation in progress proposes to establish the optimal operational parameters for the use of $M$. oleifera seed extract as a natural coagulant in the "Acuambala" community aqueduct in the city of Ibagué-Tolima.

\section{Experiments}

M. oleifera seeds were collected in their dry pods in an urban forest from Ibagué-Tolima city. The preparation of M. oleifera seeds will be carried out under the method described by Okuda et al. [4]. The seeds stored at the moment of being used, their shell, or coating will be removed manually, and later they will be pulverized in a mortar. $10 \mathrm{~g}$ of the obtained powder will be taken and it will be suspended in $1 \mathrm{~L}$ of $1.0 \mathrm{M} \mathrm{NaCl}$ (saline solution), stirring for $10 \mathrm{~min}$ to extract the active component from the seeds, then, the obtained solution will be filtered by gravity using commercial filter paper [4]. To obtain the integral 
power of the M. oleifera seed, the same steps described above will be followed without carrying out the saline extraction. The water sample will be taken from the Las Panelas stream under NTC ISO 5667-3 before the catchment point of the Acuambala community aqueduct located in the Ambalá neighborhood of the city of Ibagué-Tolima. The turbidity of the water sample was analyzed in the Laboratory for Taking and Analysis of Water and Air Samples of the Center for Industry and Construction SENA Tolima. In the jar tests, a latin square design (DCL) was applied that grouped two factors $(\mathrm{pH}$ of the water and dosage of the extract) where the coagulant action was evaluated in $\mathrm{pH}$ ranges of 4, 5, 6 and 7 and dosages of 5, 10, 15 , and $20 \mathrm{~mL}$ coagulant. As a control test, the jug test was performed on a water sample without the coagulant and a second control sample with $10 \mathrm{mg} / \mathrm{L}$ of aluminum sulfate $\mathrm{Al}\left(\mathrm{SO}_{4}\right)_{3}$ only with $\mathrm{pH}$ 7. The samples were mixed at $120 \mathrm{rpm}$ for $1 \mathrm{~min}$ and then one was mixed at $40 \mathrm{rpm}$ for $20 \mathrm{~min}$. Once finished, it was left to rest for half an hour. Finally, the percentage of turbidity removal was analyzed for each sample.

\section{Results}

The water sample shows turbidity of 500 NTU. According to the jar test, the results show a greater reduction in turbidity values was obtained under the conditions of $\mathrm{pH} 6$ with a dose of $10 \mathrm{~mL}$ of coagulant solution, and $\mathrm{pH} 7$ with a dose of $10 \mathrm{~mL}$ of coagulant solution (Table 1). The water sample without coagulant showed a $10 \%$ removal percentage and the water sample with aluminum sulfate showed a $99.8 \%$ removal percentage.

Table 1. Removal percentage of natural coagulant.

\begin{tabular}{ccccc}
\hline $\mathbf{p H}$ & Coagulant Dosage & Initial Turbidy & Final Turbidy & Removal Percentage \\
\hline 4 & $5 \mathrm{~mL}$ & 500 & 22.5 & $95.50 \%$ \\
4 & $10 \mathrm{~mL}$ & 500 & 23.57 & $95.29 \%$ \\
4 & $15 \mathrm{~mL}$ & 500 & 24.63 & $95.07 \%$ \\
4 & $20 \mathrm{~mL}$ & 500 & 12.5 & $97.50 \%$ \\
5 & $5 \mathrm{~mL}$ & 500 & 24.6 & $95.08 \%$ \\
5 & $10 \mathrm{~mL}$ & 500 & 10.49 & $97.90 \%$ \\
5 & $15 \mathrm{~mL}$ & 500 & 11.05 & $97.79 \%$ \\
5 & $20 \mathrm{~mL}$ & 500 & 9.5 & $98.10 \%$ \\
6 & $5 \mathrm{~mL}$ & 500 & 6 & $98.80 \%$ \\
6 & $10 \mathrm{~mL}$ & 500 & 2.03 & $99.59 \%$ \\
6 & $15 \mathrm{~mL}$ & 500 & 3.04 & $99.39 \%$ \\
6 & $20 \mathrm{~mL}$ & 500 & 3.95 & $99.21 \%$ \\
7 & $5 \mathrm{~mL}$ & 500 & 3.4 & $99.32 \%$ \\
7 & $10 \mathrm{~mL}$ & 500 & 2 & $99.60 \%$ \\
7 & $15 \mathrm{~mL}$ & 500 & 3.9 & $99.22 \%$ \\
7 & $20 \mathrm{~mL}$ & 500 & 4.5 & $99.10 \%$ \\
\hline
\end{tabular}

\section{Discussion}

Using M. oleifera seed powder without any previous treatment increases the organic load in the water to be treated, which decreases the efficiency of the process, as well as contributing to the formation of trihalomethanes when the water has residual chlorine [5,6] for this reason, the active agent must be extracted from the seeds, but it has been shown that these extractions continue to increase the organic load of the water, except for the $\mathrm{NaCl}$ saline solution that increases to a lesser extent the organic load [6] which is contradictory where the use of the natural coagulant of said seeds based on saline solutions $(\mathrm{NaCl})$ does not increase the dissolved organic carbon (COD) and is effective in the treatment of low turbidity waters [4]. On the other hand, state that using the coagulant extracted from the seed to a lesser extent decreases the COD [7]. In the purification coagulant high costs are required for its realization [8], which is not economically viable for community treatment plants, for this reason, only spraying and extraction were carried out.

The coagulation-flocculation processes of the extracts or natural inputs help, in addition to reducing turbidity and apparent color, to eliminate pathogens and microorganisms associated with the colloidal material that is removed, in this context, M. oleifera powder shows efficacy as a natural coagulant in the removal of cyanobacteria and the removal of odorous organic matter when oil is extracted from seeds [6]; the ability of $M$. oleifera seed extracts to remove microalgae through coagulation and flocculation processes 
have also been demonstrated [9]. Some of the reports on the efficacy of M. oleifera seed in the removal of turbidity above $85 \%$ up to $96 \%$, as demonstrated by the results, should be highlighted.

\section{Conclusions}

The saline extraction of $M$. oleifera seeds has the potential as a natural coagulant for the purification of water for human consumption. It is expected to be a first step to design accessible and low cost methods for use in community aqueducts and in populations without access to potable water.

Author Contributions: All authors contributed equally to this work. All authors discussed the results and implications, and commented on the manuscript at all stages. S.U.-F and A.T.-B. wrote the paper. All authors have read and agreed to the published version of the manuscript.

Acknowledgments: To the Servicio Nacional de Aprendizaje-SENA, for the collaboration in the logistics of the study and use of laboratory.

Conflicts of Interest: The authors declare no conflict of interest.

\section{References}

1. Asrafuzzaman, M.; Fakhruddin, A.N.M.; Hossain, M.A. Reduction of Turbidity of Water Using Locally Available Natural Coagulants. ISRN Microbiol. 2011, 2011, 1-6, doi:10.5402/2011/632189.

2. Choy, S.Y.; Prasad, K.M.N.; Wu, T.Y.; Raghunandan, M.E.; Ramanan, R.N. Utilization of plant-based natural coagulants as future alternatives towards sustainable water clarification. J. Environ. Sci. (China) 2014, 26, 2178-2189, doi:10.1016/j.jes.2014.09.024.

3. Flaten, T.P. Aluminium as a risk factor in Alzheimer's disease, with emphasis on drinking water. Brain Res. Bull. 2001, 52, 187-196, doi:10.1016/S0361-9230(01)00459-2.

4. Okuda, T.; Baes, A.U.; Nishijima, W.; Okada, M. Isolation and characterization of coagulant extracted from Moringa oleifera seed by salt solution. Water Res. 2001, 35, 405-410, doi.org/10.1016/S0043-1354(00)00290-6.

5. Alves Baptista, A.T.; Coldebella, P.F.; Cardines, P.H.F.; Gomes, R.G.; Vieira, M.F.; Bergamasco, R.; Salcedo Vieira, A.M. Coagulation-flocculation process with ultrafiltered saline extract of moringa oleifera for the treatment of surface water. Chem. Eng. J. 2015, 276, 166-173, doi:10.1016/j.cej.2015.04.045.

6. Camacho, F.P.; Sousa, V.S.; Bergamasco, R.; Ribau Teixeira, M. The use of Moringa oleifera as a natural coagulant in surface water treatment. Chem. Eng. J. 2017, 313, 226-237, doi:10.1016/j.cej.2016.12.031.

7. Alves Baptista, A.T.; Silva, M.O.; Guttierres Gomes, R.; Bergamasco, R.; Fernandes Vieira, M.; Salcedo Vieira, A.M. Protein fractionation of seeds of Moringa oleifera lam and its application in superficial water treatment. Sep. Purif. Technol. 2017, 180, 114-124, doi:10.1016/j.seppur.2017.02.040.

8. Yin, C.Y. Emerging usage of plant-based coagulants for water and wastewater treatment. Process. Biochem. 2010, 45, 1437-1444, doi:10.1016/j.procbio.2010.05.030.

9. Barrado-Moreno, M.M.; Beltran-Heredia, J.; Martín-Gallardo, J. Microalgae removal with Moringa oleifera. Toxicon 2016, 110, 68-73, doi:10.1016/j.toxicon.2015.12.001.

Publisher's Note: MDPI stays neutral with regard to jurisdictional claims in published maps and institutional affiliations.

(C) 2020 by the authors. Submitted for possible open access publication under the terms and conditions of the Creative Commons Attribution (CC BY) license (http://creativecommons.org/licenses/by/4.0/). 